\title{
PROBIOTIK UBI JALAR (POBIJAR) SEBAGAI PAKAN ORGANIK ALTERNATIF IKAN LELE
}

\author{
Davi Apriandi ${ }^{1)}$, Muh.Waskito Ardhi ${ }^{2)}$ \\ ${ }^{1,2}$ Fakultas Keguruan dan Ilmu Pendidikan, Universitas PGRI Madiun \\ email: 1avi_apriandi@yahoo.com, ${ }^{2}$ waskitoardhi@gmail.com
}

\begin{abstract}
Feed in the cultivation of catfish become the main factor affecting yield and production of catfish farmer. The dominance of pellet as feed only feed given by catfish farmer make a production of catfish farmer yield very unstable. This is because the cost of catfish farming production is mostly found in how many feed pellets consumed by catfish. High production cost caused the farmers of catfish in Wonoayu village to lose. More and more catfish ponds will be more and more seedlings of catfish stocked so that demand more feed as well. The more food that is expended, the more the farmer's production cost. Also, the problem of catfish farmers in other villages Wonoayu is the risk of death of catfish seeds at the time of initial distribution so that influences the final result at harvest. Reducing catfish death and the dependence of pellets will lower production costs to buy pellets. Alternative feed of catfish become one of the solutions of problems faced by farmer catfish in Wonoayu village. Ignorance of information and technology of making catfish feed encourages researchers to transfer the alternative feed technology from the crop of sweet potatoes combined with probiotics that feed the sweet potato probiotics (pobijar). The objectives and targets of this devotional outcome are; (1) counseling and making organic feed of sweet potato probiotics "pobijar"; (2) lowering the cost of producing catfish feed through organic food of sweet potato probiotics; (3) reducing failure in catfish culture; (4) increase yield of catfish crop production; (5) increase economic income of catfish farmers. The method used in IbM is using counseling approach and workshop of organic probiotics production of sweet potato "pobijar" as well as direct application on catfish pond as much as 2 ponds owned by head of group of catfish farmer Jaya I and 2 pond belonging to farmer group group Lele Jaya II in Wonoayu Village, District Pilangkenceng, Madiun Regency. IbM is conducted for 12 months with the following activities and work procedures; (1) preparation of probiotic samples and organic feed of sweet potato probiotics; (2) counseling how to deal with problems in catfish culture (3) workshop of making probiotics (4) feeding workshop "pobijar (5) application of organic feed of sweet potato probiotics" pobijar "at catfish pond as pilot (6) monitoring and evaluation in each farmer group. The result of this devotion is farmers can make an alternative feed that is feed probiotic sweet potato (pobijar) and provide stock as a reserve of feed during catfish enlargement process. The use of sweet potato probiotic feed can reduce the number of deaths and reduce production costs thus increasing the yield.
\end{abstract}

Keywords: Probiotics, Sweet Potatoes, Organic Feed

Abstrak. Pakan di dalam budidaya lele menjadi faktor utama yang mempengaruhi hasil dan produksi petani lele. Dominasi pelet sebagai pakan satu-satunya pakan yang diberikan petani lele menjadikan produksi hasil panen petani lele sangat labil. Hal ini disebabkan biaya produksi budidaya lele paling banyak terdapat pada berapa banyak pakan pelet yang dikonsumsi oleh ikan lele. Biaya produksi yang tinggi menyebabkan petani lele di desa Wonoayu mengalami kerugian. Semakin banyak kolam lele maka akan semakin banyak bibit ikan lele yang ditebar sehingga menuntut pakan yang lebih banyak pula. Semakin banyak pakan yang dikelurkan maka semakin banyak pula biaya produksi petani. Di samping itu masalah petani lele di desa Wonoayu lainnya adalah resiko kematian bibit ikan lele pada saat penebaran awal sehingga ikut mempengaruhi hasil akhir pada saat panen. Mengurangi kematian lele dan ketergantungan dari pelet akan menurunkan biaya produksi untuk membeli pelet. Pakan alternatif ikan lele menjadi salah satu solusi dari permasalahan-permasalahan yang dihadapi petani lele di desa Wonoayu. Kekurangtahuan informasi dan teknologi pembuatan pakan lele mendorong peneliti untuk melakukan transfer teknologi pakan alternatif dari tanaman yaitu ubi jalar yang dikombinasikan dengan probiotik yang menjadi pakan probiotik ubi jalar (pobijar). Tujuan dan target luaran pengabdian ini adalah; (1) penyuluhan dan pembuatan pakan organik probiotik ubi jalar "pobijar"; (2) menurunkan biaya produksi pakan lele melalui pakan organik probiotik ubi jalar; (3) mengurangi kegagalan dalam budidaya ikan lele; (4) meningkatkan hasil produksi panen ikan lele; (5) meningkatkan pendapatan ekonomi petani lele. Metode yang digunakan dalam IbM adalah menggunakan pendekatan penyuluhan dan workshop pembuatan pakan organik probiotik ubi jalar "pobijar" serta aplikasi langsung pada kolam ikan lele sebanyak 2 kolam milik ketua kelompok petani lele Jaya I dan 2 kolam milik ketua kelompok petani Lele Jaya II di Desa Wonoayu, Kecamatan Pilangkenceng, Kabupaten Madiun. IbM dilaksanakan selama 12 bulan dengan rencana kegiatan dan prosedur kerja sebagai berikut; (1) pembuatan sampel probiotik dan 
pakan organik probiotik ubi jalar; (2) penyuluhan cara menghadapi permasalahan-permasalahan dalam budidaya ikan lele (3) workshop pembuatan probiotik (4) workshop pembuatan pakan "pobijar (5) aplikasi pakan organik probiotik ubi jalar "pobijar" pada kolam ikan lele sebagai percontohan (6) monitoring dan evaluasi di setiap kelompok tani. Hasil dari pengabdian ini adalah petani dapat membuat pakan alternatif yaitu pakan probiotik ubi jalar (pobijar) dan menyediakan stok secagai cadangan pakan selama proses pembesaran lele. Penggunaan pakan probiotik ubi jalar dapat mengurangi jumlah kematian dan mengurangi biaya produksi sehingga meningkatkan hasil panen.

Kata Kunci : Probiotik, Ubi Jalar, Pakan Organik

\section{PENDAHULUAN}

Usaha budidaya lele berkembang di desa Wonoayu karena kebutuhan lele yang sangat tinggi terutama di wilayah Madiun sekitarnya. Desa Wonoayu juga terletak di dekat pusat pemerintahan Kabupaten Madiun yang sekarang berada di Kota Caruban. Melihat peluang tersebut beberapa warga desa Wonoayu terjun dalam pembudidayaan ikan lele untuk meningkatkan pendapatan secara ekonomi. Tetapi setelah beberapa tahun menggeluti budidaya lele, apa yang diharapkan para petani semakin lama semakin menipis karena harga pakan lele yang semakin meningkat dan hasil panen yang semakin turun.

Selain itu masalah petani lele di desa Wonoayu lainnya adalah resiko kematian bibit ikan lele pada saat penebaran awal sehingga ikut mempengaruhi hasil akhir pada saat panen. Hal yang kurang diperhatikan adalah terkait dengan kualitas air. Pada umumnya ikan-ikan budidaya air tawar menghendaki suhu air berkisar dari $26-30^{\circ} \mathrm{C}$. Apabiladibandingkan dengan kisaran normal ini, kisaran suhu air kolam yang dipakai untuk memelihara ikan wader masih memenuhi syarat untuk tumbuh optimal. Suhu yang optimum bagi ikan sangat diperlukan supaya pertumbuhannya jugaoptimal (Budiharjo, 2003).

Pengelolaan kualitas air yang dilakukan oleh petani lele desa wonoayu masih cenderung melihat berdasarkan warna dan bau air. Ketika warna air menghijau dan bau tidak sedap baru air diganti. Hal tersebut dapat menyebabkan kematian lele karena keracunan amoniak. Padahal pengelolaan kualitas air yang baik harus dilakukan penggantian air $10 \%$ setiap hari. Selama pemeliharaan suhu berkisar $25-32^{\circ} \mathrm{C}$, oksigen terlarut berkisar $5,7-8,2 \mathrm{mg} \mathrm{L}-1$, total amoniak nitrogen berkisar 0,147-0,816 mg L-1, dan $\mathrm{pH}$ berkisar 7,13-7,87. (Hasrah, 2016).
Selain masalah pakan dan pengelolaan air yang belum baik, pembudidaya lele juga dihadapkan pada permasalahan lain yaitu kualitas lele semakin menurun yang mengakibatkan hasil panen menurun. Kualitas lele yang menurun dilihat dari penurunan bobot per satuan waktu pemeliharaan, penurunan ketahanan terhadap berbagai penyakit diantaranya cacar dan luka kulit, sungut keriting dan putus, insang merah/hitam, sirip geripis, perut buncit dan merah, hilang keseimbangan, jamur, dan bau kolam karena amoniak. Oleh karena itu perlu adanya inovasi untuk menjawab masalahmasalah tersebut.

Oleh karena itu dibutuhkan solusi di dalam mengatasi permasalahan-permasalahan yang dihadapi petani lele. Salah satu solusi untuk mengatasi permasalahan-permasalahan di atas adalah, yaitu dengan cara membuat pakan yang tidak hanya mencukupi gizi, tetapi juga harus mampu memberikan ketahanan lele dari serangan penyakit.

Ubi jalar (Ipomea batatas L.) merupakan tanaman semusim yang tumbuh di daerah tropis. Ubi jalar mengandung banyak karbohidrat, provitamin $\mathrm{A}$, vitamin $\mathrm{B}$, vitamin $\mathrm{C}$, mineral, dan sedikit lemak serta protein. Ubi jalar ungu juga mengandung oligosakarida terutama rafinosa, stakhiosa, dan verbakosa. Oligosakarida dapat mencegah sembelit, tetapi pada orang yang sangat sensitif dapat mengakibatkan kembung. Oligosakarida yang terkandung dalam ubi jalar ungu bersifat fungsional karena tidak dapat dicerna oleh enzim-enzim pada pencernaan manusia (Silalahi, 2006).

Oligosakarida yang terkandung dalam ubi jalar merupakan prebiotik bagi bakteri baik yang menguntungkan untuk kesehatan karena merangsang pertumbuhan atau aktivitas kelompok mikroba bifidobacterium di dalam kolon (usus besar). Bifidobacterium merupakan 
bakteri asam laktat yang hidup di dalam usus besar manusia atau hewan. Bakteri ini mampu menghasilkan vitamin B kompleks dan mencegah pertumbuhan bakteri patogen. Oligosakarida tidak aktif secara fisik, tetapi memiliki efek biologis yaitu memudahkan fermentasi oleh mikroorganisme yang menguntungkan dalam kolon (Silalahi, 2006).

Probiotik merupakan makanan tambahan (suplemen) berupa sel-sel mikroorganisme hidup yang memiliki pengaruh menguntungkan bagi hewan inang yang mengkonsumsinya melalui penyeimbangan flora mikroorganisme intestinal dalam saluran pencernaan (Irianto, 2007).

Menurut Irianto (2003), pemberian organism probiotik dalam akuakultur dapat diberikan melalui pakan, air, maupun melalui perantaraan pakan hidup seperti rotifera atau artemia. Pemberian probiotik dalam pakan, berpengaruh terhadap kecepatan fermentasi pakan dalam saluran pencernaan, sehingga akan sangat membantu proses penyerapan makanan dalam pencernaan ikan. Fermentasi pakan mampu mengurai senyawa kompleks menjadi sederhana sehingga siap digunakan ikan, dan sejumlah mikrooraganisme mampu mensistensa vitamin dan asam-asam amino yang dibutuhkan oleh larva hewan akuatik. Pemberian probiotik pada pelet dengan cara disemprotkan dapat menimbulkan terjadinya fermentasi pada pelet dan meningkatkan kecepatan pencernaan. Selanjutnya akan meningkatkan konversi pakan ikan, peternakan dapat memproduksi lele ukuran layak jual dalam waktu lebih singkat (60-70) hari sehingga dapat menekan biaya produksi.

Probiotik organik merupakan teknologi penyeimbang lingkungan hidup yang paling aman. Keunggulan yang di dapat pada sistem budi daya probiotik organik adalah biaya pakan pada budi daya lele dapat mencapai $60-70 \%$ dari keseluruhan total biaya produksi. Karena itu, setiap terjadi kenaikan harga pakan sangat mempengaruhi pembudidaya lele.Manfaat dari probiotik adalah mengatur lingkungan mikroba pada usus, menghalangi mikroorganisme pathogen usus dan memperbaiki efisiensi pakan dengan melepas enzim-enzim yang membantu proses pencernaan makanan (Dhingra, 1993).
Berdasarkan permasalahan tersebut alternatis solusi untuk mengatasi pemasalahan petani lele di desa wonoayu adalah melalui teknologi pembuatan pakan organik probiotik ubi jalar.

\section{METODE PELAKSANAAN}

Metode Pelaksanan yang dilakukan untuk mengatasi permasalahn petani lele desa wonoayu adalah sebagai berikut:

1. Mengadakan penyuluhan kepada kelompok petani lele jaya Desa Wonoayu tentang manfaat pakan organik probiotik ubi jalar.

2. Pembuatan Sampel Probiotik

3. Melakukan diskusi interaktif untuk memberikan informasi teknologi dan pengetahuan yang up to date tentang seluk beluk budidaya lele sekaligus tukar pendapat.

4. Melakukan sosialisasi untuk merubah pemikiran tentang hasil akhir produksi ikan lele yang menitikberatkan pada bobot atau berat lele.

\section{HASIL DAN PEMBAHASAN}

Pelaksanaan program pengabdian masyarakat ini dimulai dengan melakukan penyuluhan di rumah petani lele Bapak Anang Wonoayu tentang pengenalan dan potensi probiotik ubi jalar (pobijar) sebagai alternatif pakan yang memiliki kandungan gizi dalam proses budidaya lele. Penyuluhan diberikan kepada kurang lebih 30 orang masyarakat desa Wonoayu yang terdiri dari unsur masyarakat dan anggota kelompok tani Jaya I dan II desa Wonoayu. Setelah melakukan penyuluhan selanjutnya masyarakat diajak dalam pembuatan probiotik ubi jalar secara mandiri dengan memanfaatkan bahan-bahan dari sekitar yang mudah di cari khususnya bahan yang digunakan adalah bahan ubi jalar. Tahap selanjutnya adalah praktek penggandaan pakan probiotik ubi jalar dengan menggunakan ubi jalar sebagai sumber protein tinggi atau karbohidrat untuk lele. Praktek pembuatan probiotik ubi jalar (pobijar) ini dimaksudkan untuk memberikan solusi kepada masyarakat tentang penyediaan pakan dan peningkatan hasil panen lele sehingga ke depannya bisa mengurangi pengeluaran dan meningkatkan hasil panen lele serta dapat 
memanfaatkan pakan alternatif melalui sumber pakan yang didapatkan dari sumber sekitar khususnya ubi jalar. Pelatihan dilanjutkan dengan tata cara penggunaan probiotik ubi jalar (pobijar) selama budidaya ikan lele. Aplikasi probiotik ubi jalar (pobijar) ke lingkungan di lakukan dengan menyiapkan 4 kolam lele dengan ukuran $6 m \times 3$ $m$, setiap kolam berisi 3000 bibit lele. Dari 4 kolam yang dipakai sebagai percontohan menunjukkan hasil yang signifikan karena pemakaian probiotik ubi lele ini. Hasil dari kegiatan yang dilaksanakan tentang probiotik ubi jalar (pobijar) memiliki respon yang baik dari masyarakat sekitar serta petani lele di Wonoayu, hal tersebut dapat dilihat dengan antusiasnya masyarakat Wonoayu dalam mengikuti kegiatan dan mepraktekan pembuatan probiotik dengan bahan ubi jalar sebagai bahan utama ubi jalar untuk pakan lele yang akan digunakan sebagai peningkatan hasil atau pembudidayaan lele khusus petani Jaya I dan II.

Setelah melakukan pelatihan pembuatan probiotik Tim abdimas juga mensosialisasikan cara komersialisasi probiotik ini sehingga dapat meningkatkan penghasilan tambahan masyarakat petani lele Jaya ini, karena mereka sudah dibekali cara pembuatan pakan probiotik melalui ubi jalar serta bagaimana cara penggandaan probiotik yang ada sebagai starter pakan lele.

Target luaran selanjutnya adalah pendampingan pembuatan pakan alternatif probiotik ubi jalar (pobijar) untuk menunjang proses produksi dan keberlanjutan stok pakan dan dapat melakukan pemasaran pakan yang diharapkan dapat dijadikan sebagai sumber alternatif peningkatkan ekonomi melalui penyebaran dan penjualan kepada masyarakat lain sesama petani. Pendampingan produksi pakan alternatif probiotik ubi jalar ini perlu dilakukan karena di rasa perlu demi terwujudnya home industry pakan lele probiotik ubi jalar.

\section{SIMPULAN DAN SARAN}

\section{Kesimpulan}

Berdasarkan hasil yang telah dicapai sebanyak $70 \%$ dari kegiatan pengabdian masyarakat ini maka dapat disimpulkan:

1. Program pengabdian masyarakat tentang pembuatan pakan probiotik ubi jalar ini terdiri dari beberapa tahap dimulai dengan penyuluhan/sosialisasi, pembuatan pakan, pendampingan di lapangan, dan pembuatan buku pembudidayaan.

2. Antusiasme masyarakat terhadap program ini sangat tinggi hal ini dibuktikan dengan adanya peran serta masyarakat langsung dalam proses kegiatan awal sampai tahap ini. Rasa ingin tahu yang tinggi terkait penggunaan bahanbahan di alamyang dapat digunakan sebagai pakan alternatfi sehingga mengurasi biaya pakan pelet.

\section{Saran}

Saran dari pengabdian ini adalah:

1. Perlu adanya pendampingan secara periodik kepada petani lele dalam pembuatan pakan dan probiotik, pembuatan pakan, cara memberikan pakan basah dan masa panen

2. Diperlukan kajian dan solusi bagi petani lele dengan kondisi daerah yang memiliki kondisi air yang kurang pada musim kemarau.

3. Kajian lebih lanjut tentang pemanfaatan probiotik dan pakan alternatif ini pada ikan air tawar lainnya sehingga program IbM tidak hanya dilakukan pada budidaya lele saja akan tetapi untuk budidaya ikan air tawar potensial lainnya.

\section{DAFTAR PUSTAKA}

Amiri, M. S. dan Yousefian M. (2009). A Review of The Use Of Prebiotic In Aquaculture for Fish and Shrimp. African Journal Of Biotechnology Vol. 8 (25), pp. 7313-7318.

Budiharjo, Agung. 2003. Pakan Tambahan Alternatif untuk Meningkatkan Pertumbuhan Ikan Wader (Rasbora argyrotaenia). BioSMART Vol. 5, No. 1, April 2003, hal. 55-59.

Dhingra, M.M. (1993). Probiotic In Poultry Diet Livestock Production and Management. Sania Enterprises Indore. 452001, India

Irianto, A. (2003). Probiotik Akuakultur. Gajahmada University Press. Yogyakarta.

. (2007). Potensi Mikroorganisme: Di atas Langit ada langit. Ringkasan orasi 
ilmiah Fakultas Biologi Universitas Jendral Soedirman. Tanggal 12 Mei.

Silalahi, 2006. Makanan Fungsional. Yogyakarta: Kanisius 